\title{
The Residential Care through the Children's Perspective: Physical and Social Aspects of the Context
}

\author{
Dalízia Amaral Cruz, Celina Maria Colino Magalhães, Laiane da Silva Corrêa \\ Federal University of Pará, Belém, Brazil \\ Email: celinaufpa@gmail.com
}

Received 18 February 2016; accepted 16 May 2016; published 19 May 2016

Copyright @ 2016 by authors and Scientific Research Publishing Inc.

This work is licensed under the Creative Commons Attribution International License (CC BY). http://creativecommons.org/licenses/by/4.0/

(c) (i) Open Access

\section{Abstract}

The present article investigates the perspective of children about the institutional context, considering the physical and social aspects of the environment, taking part of the research six children from a shelter in the metropolitan region of Belém/Pará/Brazil. For the data collection were used semi structured interviews and children's stories. The interviews were fully transcribed for content analysis from which were extracted the following categories: social aspects of the environment: interactions and activities established in the institution; and physical aspects of the environment: variety and availability of objects. To what concerns the social aspects, the main results show that the children were free to play in different areas of the institution, enabling interactions among siblings. Moreover, the activities performed outside the institutional environment, such as tours, were much appreciated by the children. Regarding the physical aspects, the institution had a great variety of objects, as toys, to which the children had access. Even though some of the objects were shared among the children, such as clothes and toys, some of the strategies of the staff were to value the individuality and subjectivity of the children. Therefore, it was possible to debate through the children's perspective some important aspects related to the physical and social context of the residential care.

\section{Keywords}

Perspectives, Children, Institutional Environment

\section{Introduction}

The promulgation of the Children and Adolescent Statute (ECA-Estatuto da Criança e do Adolescente) in 1990

How to cite this paper: Cruz, D. A., Magalhães, C. M. C., \& da Silva Corrêa, L. (2016). The Residential Care through the Children's Perspective: Physical and Social Aspects of the Context. Creative Education, 7, 899-909. 
represented a crucial change in the paradigm of assistance to children and adolescent. In this sense, children and adolescents started to be considered subjects of right in a specific condition of development. Although there is a large distance between what is granted by the law, the judicial speech, the Brazilian reality, and the current social and professional practices. ECA (Brazil, 1990) by referring to specific protective measures, recommends some modifications, supposing the residential care is understood as a provisory and exceptional measure, with no implications to the deprivation of freedom. Therefore, it attempted to halt some practices of internment, exclusion, and control, which marked the history of institutionalization in the past.

For that reason, it is apprehended that residential care may constitute a context that promotes the development of children and adolescents, regardless of the time they stay in the institution, for they are people going through the process of development (Corrêa \& Cavalcante, 2013; Siqueira \& Dell'Aglio, 2006). Thus, the shelter, as part of the context where their development takes place (Rossetti-Ferreira, Serrano, \& Costa, 2011), must value and respect the children's voice/opinion, according to the Technical Orientations for the Sheltering Services for Children and Adolescents (Orientações Técnicas para os Serviços de Acolhimento para Crianças e Adolescentes-Brazil, 2009), along with their individuality and subjectivity, even though the institution is an environment marked by collectivism (Cavalcante, Costa, \& Magalhães, 2012; Corrêa, 2011).

In the national literature, some papers debate this perspective of giving voice to children (Amaral, Magalhães, \& Corrêa, 2015; Platilha, Magalhães, \& Pedroso, 2014; Alves \& Emmel, 2008; Garzella \& Serrano, 2011; Silva \& Magalhães, 2011; Almeida, Maehara, \& Rossetti-Ferreira, 2011; Prada, Williams, \& Weber, 2007). According to Thorne (2002), for a long period of time the children had their voices and experiences disregarded. In the research scope, even though they were always present, they were treated solely as study objects. Nonetheless, this fact has been going through changes, and some national (Trivellato, Carvalho, \& Vectore, 2013; Souza \& Castro, 2008) and international researches (Christensen \& Prout, 2002; Elbers, 2004; Thorne, 2002) have considered the children as collaborators during the research, with right to their voices.

Christensen and Prout (2002) identified four different ways the child is approached in the research field about childhood. Among them, the child had the role of social actor, participant, and collaborator. As a social actor, it is comprehended with its own experiences and understandings; it has influence and is influenced by the social and cultural world it lives in. This approach is amplified by the perspective that considers the child as a participant and active collaborator in the research process. For that, all the activities that affect the children's life (including the research) must conceive them as human beings and as active citizens. Bronfenbrenner (2011) agrees with this reasoning by stating that children are active participants and have influence on the course of their development, they must not be comprehended as inserted to some context, however as being part of the this context, for the process as well as the results of human development are "a joint function of the characteristics of the environment and the person" (Bronfenbrenner, 2011: p. 145).

Bernardi (2010b), thus, drives attention to the importance of making the experiences lived in the shelter to be reported, analyzed, and covered in meaning for the sheltered children and adolescents and also for their families. In agreement with these thoughts, Amaral et al. (2015), and Platilha et al. (2014), restate the importance of professionals from several areas that are willing to study the experiences and perceptions of children in residential care to create areas that favor listening to these children, especially for them to have guaranteed their right to speak.

According to Trivellato, Carvalho and Vectore (2013), understanding the children as capable, listening to them, and valuing their experiences through their voices, are attitudes that may favor the manifestation of important aspects of their subjectivity and become a path for interventions that benefit the infantile development and positively potentiate the services provided to this population. Activities as children stories and free plays (Alves \& Emmel, 2008; Pontes \& Izar, 2005; Martins \& Szymanski, 2004) in the context host are some enabling strategies for such perspective.

It is crucial, therefore, to know the senses that are attributed, to be alongside them, and know what they think and feel about their experiences. In this sense, this study is based on the systemic view of Bronfenbrenner (1996, 2011), focusing chiefly in the microsystem, valuing the perception of children about the physical and social aspects of the residential care.

In the immediate context (microsystem), according to Bronfenbrenner (1996), how the environment is perceived by the child is essential to how it would behave and to its development. As the child has an active role throughout its development, it is relevant that its voice is heard and valued in order for the perception it has about the sheltering institution to be apprehended; in addition to the objective characteristics of the context it is 
also relevant the reality as it exists in the subjective world of the person (Bronfenbrenner, 1996, 2011). Therefore, the objective of this research was to investigate the perspective of children on the institutional context, considering the physical and social aspects of the environment.

\section{Method}

\subsection{Design}

This consists on a qualitative research that is characterized by considering the natural environment as a direct source of data and the researcher as a fundamental instrument. Moreover, it has a descriptive character, in which the child's voice is apprehended as an important element of discussion and orientation of the sheltering services. This is, therefore, an investigation used for the comprehension of phenomena characterized by a high degree of intern complexity (Minayo, 2010).

\subsection{Participants}

Six six-year-old children of both genders (five girls and one boy) sheltered in a governmental institution for children. The inclusion criteria were: 1) to be housed in the institution for at least two months; 2) be as old as 6 or 7 ; 3) absence of any type of disorder; and 4) accept to be part of the research. It is noteworthy that the criterion used for the age selection was due to the verbal skills the child has at that age, that enable the necessary communication due to the nature of this study.

\subsection{Contextualization}

The institution is settled in the metropolitan region of Belém, in the state of Pará, it attends children who are in a situation of social vulnerability, with ages between zero and six years old, and works in the same patterns as institutional shelters attending large groups. It attends an average of 50 children every month, and during the data collection it had 102 educators, including the ones on duty and daily paid. The children were dispersed in seven dormitories, according to age criterion.

The place used for the data collection was a room in the educational department of the institution. For the storytelling activity the chairs were arranged in a circle to ease the visual contact the researcher had with the children, and for the children with the stories.

\subsection{Instruments and Materials}

Six children stories were used: When I Feel Angry (Quando me sinto zangado) — a rabbit tells what makes him angry and what does not to sulk; The Three Little Pigs (Os três porquinhos) - tells the story of three little pigs who left the parents' home to build their own homes; The Ugly Duckling ( O patinho feio) - It is the story of a duckling that goes away from home for being considered ugly; Where the wild things are (Onde vivem os monstros) - It is the story of a boy (Max), who after a prank is grounded by the mother. In hisroom a forest appears and he travels to where the monsters live, becoming the king; A mother for Choco (Choco encontra uma mãe)tells the story of a bird (Choco), which sets out to find an animal to be his mother; Everybody feels: happy (Todo mundo fica feliz) - Julia and Caio talk about an event in their lives. Julia talks about herbirthday party and Caio talks about a trip he made with his family. The criteria used to choose these stories were: 1) adequate reading, considering the content of the story and the children's age; 2) plot that enables the discussion of the children's experiences in the shelter; 3 ) tale, due to the short time.

Moreover, six semi-structured interview scripts were used, created by the researcher to obtain information about the children's perception regarding their experiences in the institution. For every storytelling activity a script with questions was created, making reference to specific parts of the narrative, in order to connect the ideas, using questions coherent to the plot. Finally, it was adopted the field diary that allowed the researcher to $\log$ her perceptions about the ecologic environment where the activities took place, as materials were used a camcorder to record the storytelling, and paper and pen for general notes.

\subsection{Procedure}

The data were collected during the storytelling activities through interviews. The activities with the stories were 
performed in six different instances; each meeting corresponded to one story along with the interview. In average, each activity lasted 15 minutes. The storytelling and the interview were performed by the researcher. The interviews were performed during the storytelling as a conversation.

Six stories were used, two of those deal specifically with feelings: "When I feel angry"-feeling of anger, and "Everyone is happy"-feeling of happiness/joy, the remaining four: "The Three Little Pigs", "The Ugly Duckling", "Where the Wild Things Are", and "A Mother for Choco" had a common theme, the removal of the protagonist's home. It was decided to start and finish the activities with stories about feelings.

Therefore, in the first meeting, the children were asked to choose the name of a character they would be identified throughout the research. Each meeting was organized in three moments: 1) the children were taken to the room where the activity would happen, a short time was given for them to organize themselves and for setting up the camcorder; 2) from the second meeting on, the children were asked to talk about the story from the previous day; 3 ) then the researcher would present the story to be worked with, started telling the story, and made the interviews. It is important to mention that the seventh day was necessary so the children could talk about the story told on the sixth day.

\subsection{Data Analysis}

The interviews were fully transcribed for the content analysis, making use of the analysis technique proposed by Bardin (2011), which comprises a set of techniques for the analysis of the communication with the purpose to make a systematic and descriptive inference about the content of the messages. This way, the data were structured deriving out of semantic categories that emerged from the children's speech, represented by themes and correlated to physical and social characteristics of the host institution: 1) social aspects of the environment: interactions and activities established in the institution; and 2) physical aspects of the environment: variety and availability of objects.

The first category involves the verbalizations of children that refer to the contact among themselves, among siblings, and in activities promoted by the institution. The second category brings emphasis to the children's report that refer to a set of instruments and objects that were part of the institutional environment, related to material goods.

\subsection{Ethics Considerations}

The research project "Perceptions of children in shelters: environments and relational forms" to which this project is linked, was submitted and approved under the No. 146/11 by the ethics committee in research with human beings from the science and health institute of the Federal University of Pará CEP-ICS/UFPA, in addition to consent from the legal representative of the institution and from the childhood and youth court.

In order the preserve the children's identity their names were replaced by famous characters chosen by them on the first day of data collection. Moreover, as it is a study that involves children and deals with emotional and delicate contents, two psychologists from the institution were invited to take part in the data collection, in a way to guarantee a specialized attendance/welcoming in case of emotional mobilization by the children.

\section{Results and Discussion}

The data are going to be presented through two categories about the children's host experiences extracted from the interviews performed along the activities with the stories and divided according to the physical and social aspects of the institutional context: social aspects of the environment: interactions and activities established in the institution, and physical aspects of the environment: variability and availability of objects.

\subsection{Social Aspects of the Environment: Interactions and Activities Established in the Institution}

In this category it was possible to elucidate the social characteristics of the institutional context through the children's voice. In that way, when asked about what would be the first order to the shelter if they were "kings" like the character of the story "Where the wild things are", a discussion among the children is raised by a reply given by Barbie in extract 1, making reference to a play situation among them. 
Barbie: I would tell her (pointing to Cinderella) to shut up when (...) we is (are) playing (...). She threw things, hit everybody with the belt (...). Snow White: Yes, she took the belt (...) she paft (onomatopoeia of the sound of the belt) on my back, I didn't feel a thing (she stands up from the chair, leans forward and places her hand on her back). Barbie: It's a lie (she makes gestures with her hands in a negative way) it was in front of him (pointing to Superman). Cinderella: It's a lie; it was on Captain Hook like this, $b a c$ (onomatopoeia of the sound of the belt). Police: then he didn't do anything. Cinderella: then (...) I said, look, get outta here Beauty, or I'll hit you again (showing as if she were holding a belt on her hand).

It is observed that extract 1 reveals a playful context among the children. The interactions established among them illustrates what Batista (2012) states that by means of play, make-believe, the child can reach the imaginary and symbolic order and put itself actively in scene. The play enables, therefore, the extension of experiences from the real world to the symbolic one.

It is important to consider, as well, the play as a molar activity, a significant form of behavior, for having meaning for the participants of the environment, being considered a manifestation of/or influence on the development, as clarified by Bronfenbrenner (1996). Thus, when Barbie referred to an event that happened at another place and time, alongside with the other children, shows us the expansion of her phenomenological world beyond the immediate situation.

In the study performed by Alves and Emmel (2008), the verbal content of children during the plays and in the conversations, after the activities with the children stories, showed some moments that allude to their life history. Hence, it is possible that Cinderella (when hit the other children) had recreated in the play a situation from her family living, on account of punishing the children by "belting" wasn't something the educators of the institution used to do. This may indicate a repetition of experiences or even the reproduction of social/family practices that are engraved in the child's routine (Martins \& Szymanski, 2004).

Cinderella, as well as Barbie, invokes immediately an event that is not concretely present, which makes us converge with Bronfenbrenner (1996), when he states that it is important for us to look at the interactions content, where the activities must be considered on its interpersonal context, because they reflect the level of psychological growth of the person under development. So when the children talk about the fact that happened in the play, which took place last, they are demonstrating a capacity they have in creating a mental mesosystem (articulated set of microsystems and events elsewhere), so that it is possible to talk about an "ecology of mental life" which presents potential structure with the same shape of the ecological environment (Bronfenbrenner, 1996).

From what has been exposed, it is evident the importance of play as "context in which the child acquires abilities and social knowledge" (Pontes \& Izar, 2005: p. 85). Moreover, according to Garzella and Serrano (2011), it is crucial to have guaranteed areas and moments in the shelter for the children to play, some spaces that favor them to express themselves, where the free play is included, for their content might give some hints on the interactions the children have with their families, as it was seen in Cinderella's behaviors of "belting" her colleagues, as well as with its peers and other adults. Hence, offering to the children some spaces that enable and encourage them to partake in a variety of spontaneous activities, as the plays, either with an adult, by itself, or with other children (Bronfenbrenner, 1996), it is extremely important that the host institution promotes their development.

The results also suggest that there are interactions among siblings in the institution, as illustrated by extract 2 , in which the story "The Ugly Duckling” was told.

Researcher: (...) who has sibling here in the shelter? Beauty and Barbie raised their hands (...). Police: I have a sister. Researcher: Do you play with your siblings here in the shelter? (...) Police: I play (...). Barbie nods positively. Cinderella: I have a brother here in ... it is Augusto (smiles and recoilby the psychologist). Researcher: Really? Cinderella, do you play with him here? Police: mine is Narizinho (character from a Brazilian story_ "O Sitio do Pica-pau Amarelo"). Researcher: Is she Narizinho? Cinderella: I have two, I have two brothers. Police: Alexandre and Augusto (pointing to Cinderella). Researcher: Hum, ok, and what do you play? What do you play [of]? Barbie: I play of that thing with my brother (swings her arms up and down, resembling a seesaw).

Motivating the contact among siblings in the institution is crucial for maintaining their bonds, for the interaction favors them to share experiences and feelings. That's why it is important to pay attention to the content and the quality of the relationships inside the institution, once they are sensible to contextual conditions in which the 
siblings live. Moreover, they depend on the opportunities provided for establishing sociability as a protecting aspect for the development (Cavalcante, Costa, \& Magalhães, 2012).

Cavalcante, Costa, \& Magalhães, (2012) indicate the need to rethink some measures that in addition to guarantee the sheltering of siblings, they provide adequate conditions to preserve the groups and bonds capable of keeping them together. In this sense, the intervention must broaden the conditions to ensure, among other things, the construction of especial dormitories for groups of siblings, chiefly during the period of adaptation to the institution.

Consistent with this line of reasoning, Costa, Magalhães and Pedroso (2014) emphasize the need for the host institutions to favor the fraternal bonds, as providing specific dormitories to welcome the siblings; according to extract 2 and data from the field diary, it was observed that the interactions among siblings would happen in the open spaces in the institution (hallways and playground), as the institution didn't have specific dormitories for siblings. The open areas were the places the siblings would look for each other to be together. Moreover, these areas would give the children the opportunity to know the other children's siblings.

In the same direction of this discussion, in the institutions investigated by Almeida, Maehara and RossettiFerreira (2011), their functioning was organized based on the age of the welcomed children, in the same manner it was organized in the institution in which this research took place. In this sense, the authors point out to how the host institutions operate nowadays, for the distribution of dorms by age and the routine structure are not organized to encourage and motivate the relationship among siblings.

It is important to ponder that the conditions granted by the social context contribute for the children to construct and/or maintain some reference figures in the institution including the siblings, because they constitute dyads as important as the ones constituted in other ecological environments outside the family (Bronfenbrenner, 1996). In these terms, siblings are sources of support for the ecological transition, whatfavor the adaptation to the new context, as well as for the process of reintegration to the family. To Almeida, Maehara and RossettiFerreira (2011), as it is a priority that the children go back to living with the family, it is important to promote extensive interactions with regards to maintaining and strengthening the bonds. The "blood ties" are not sufficient for these bonds to be created and maintained. It is imperative to elaborate a careful work in the host institutions that enable the family bonds (Amaral, Magalhães, \& Corrêa, 2015; Almeida, Maehara, \& Rossetti-Ferreira, 2011), also among siblings.

However, the results of these studies demonstrate that despite the type of institutional organization that disperse the children by age in the dorms, the fact that they can walk around the open areas of the institution (note from the field diary) somehow favors the peers of siblings to meet and interact. In extract 2 Barbie tells that she plays at the seesaw with her brother. Additionally, Police's speech shows some indicatives that some of them know the other children's siblings, when he mentions the name of Cinderella's brothers. The results of the research developed by Platilha et al. (2014) show that the children who had sheltered siblings showed to be more intimate to each other than to other children.

The free circulation of the children in the open areas of the institution is a positive aspect of the social environment of the institution, because it promotes the meeting of siblings and children from different ages, also their engagement in plays (note from the field diary), which favors sharing feelings, desires, and emotions among the children, and also among them and the adults. Those interactions enable learning, as well as conceptions and meanings to be built (Garzella \& Serrano, 2011). In shelter the proximal processes established among the children and the other people with whom they interact are the closest support net they have, that's why it is essential that the structure (physical aspect) and the operation (social aspect) of these environments are effectively organized to and with the children.

To Bronfenbrenner (1996), the interactions among children and adults, and among children with different ages, are very important for the development, especially for the younger ones due to the establishment of the power balance that helps the person in development to learn how to conceptualize and deal with different relations of power. Therefore, the interactions among coetaneous and among non-coetaneous peers are relevant for the child's developmental path.

Regarding the activities accomplished with the children, the ones performed outside the institution are much appreciated by them. When asked about what would make them happy in the shelter they answered as illustrated by extract 3. The story told was "Everybody feels: happy".

Researcher: And here in the shelter, what makes you happy? Beauty: Playing. Snow White: I...they let 
me go on the tours from the shelter. Little Red Riding Hood: Me too, they let me go on the tours. Researcher: Really? (...) and you, do you go on the shelter's tours? Bella: Yes. Researcher: and where do you go? Police: to the park (...). Barbie: I go to the beach (...). Bella: I go to the square. Researcher: Which place you visited that you liked the most? Cinderella: I like to go to the beach. Little Red Riding Hood: Every day I would go out with the aunts to go to the park. Police: I'd go to the woodland (Bosque).

The organization of tours with the children point to another positive social aspect of the institution, for it grows apart from the old conception that marked the history of institutionalization of children, considered being a segregating environment that confines and keeps the children in deprivation of interactions with the community. Thus, the data suggest that adopting actions, as the ones mentioned, by the institution is in agreement to what is stated by the ECA and the "Technical Orientations for the Sheltering Service for Children and Adolescent" (Brazil, 2009), that postulate the preservation and strengthening of community bonds of children and adolescents attended in sheltering services. The interaction with the community is important for a healthy development, once it favors the identity formation and their constitution as subject and citizen (Brazil, 2009).

In the study of Prada, Williams and Weber (2007), with the exception of attending schools, the children would not have any activities outside the institution. Almeida, Maehara et al. (2011) emphasize the importance of shelter spaces to provide the relationship of the children with the community in a more personalized and meaningful way for each one.

The children that participated in this investigation, besides the tours mentioned, also attended school, and in one occasion during the data collection, the researcher went to church with them for a thematic mass (Note on the field diary). Nevertheless, Almeida et al. (2011) call attention to the caution in favoring the formation of "group of sheltered children", for the fact that many children of the same institution attend the same spaces of the community at the same time, what makes it difficult for them to interact with other children.

Bernardi (2010a), about the guiding principles for the institutional sheltering services, confirms one of the principles defined by the ECA and reaffirmed by Brazil (2009) about the participation of children and adolescent in the social life and in socio-educative activities, inside and outside the institution. He highlights that this kind of participation must be stimulated, respecting the opinion of the attended children and aiming at their learning and development, as well as a gradual increase in personal and social autonomy.

Birthdays celebrations, in the format of "birthdays of the month", are also an activity promoted by the shelter: once a month the institution would have a "small party" to celebrate the birthday of children born in that month. Extract 4 illustrates the moment in which the children talk about their birthdays. The story told was "Everybody feels: happy".

Researcher: (...) Who already had a birthday party? (Barbie, Beauty, Cinderella, Snow White, Police and Little Red Riding Hood raised their hands). Researcher: And where was it... (Cinderella interrupts) Cinderella: I was the first, it was here, right there (pointing towards the door). Researcher: Was it? Cinderella: Hey aunt, it was my birthday (...). Police: It was hers and Beauty's. Cinderella: And it was also in the country dance carnival. Police: It was Bella's birthday. Little Red Riding Hood: I was the second. Researcher: And how was this party? Was it nice? Little Red Riding Hood: Nods positively.

The entrance to the institution is an important ecological transition in the life of these children; there are considerable changes in the structure of interpersonal relationship, in the activities performed, and in the roles played. According to Bronfenbrenner (2011: p. 83), the ecological transitions "have consequences to the human development that includes the person in new activities and in other types of social structure". Therefore, the institution becomes part of its history, the affective relationship built are going to be part of its psychological field. That's why it cannot be deleted from the life of these children, due to the crucial role it has in their subjective constitution and it is also part of their mental ecology.

Hence, promoting activities as the above mentioned in the institution may indicate the quality of the social environment, for a set of variables may favor the development of children with their individuality and subjectivity. Elage (2010) emphasizes the register of life histories as important strategies to materialize and demonstrate the value each child has, attributing to it a special place in the construction of its own biography, inviting it to place itself ahead of its own history. This is also a way to bring about the children as single individuals. Also, in a context that is characterized by collectivity, as the host institution, the elaboration along with the children of a sketch-book with reports of their experiences, pictures, drawings, and other graphic materials, is a rich alterna- 
tive for building their memory. Vidigal (2010), by approaching the "Making History Project" gives some hints on how to help the children to elaborate their memory sketch-book, recommending some information to be part of the book. Among the information, he suggests that the shelter must be added, having among other things, reports and pictures of the activities developed in the institution, parties, important dates as birthdays, Christmas, Children's day, etc.

It is possible to observe in extract 4 that it makes a difference for the children to be the firsts or not to celebrate their birthdays: Cinderella: "I was the first, it was here, right there (...)"/Little Red Riding Hood: “(...) I was the second". It is worth highlighting, yet, Cinderella's speech: "and it was also in the country dance carnival." She brings in her speech two festive events that the institution also celebrates - the carnival and the June party.

Organizing the children's autobiographic events makes it easier for them to appropriate their own history. Although they celebrate their birthdays with other children, their individuality will be valued either in a photo album or in a diary. It is understood that some rules of the organization are necessary for it to work properly, however, some initiatives like those ones enable the construction of feelings due to experiences from the past and the present of these children. Additionally, having the family reintegration as the main purpose, the institutions must articulate their functioning according to the families' possibilities and promote concrete means of communication and contact to their children (Almeida, Maehara, \& Rossetti-Ferreira, 2011), allowing them to be part of the daily activities of the institution, not only at stipulated visit periods, but also sharing important moments in the life of their children, as the birthday celebration and other festive dates.

\subsection{Physical Aspects of the Environment: Variability and Availability of Objects}

In this category it was possible to identify the physical characteristics of institutions, by the availability of objects for the children. When asked about what they consider cool at the institution, the children replied in extract 5 , occasion in which the story "The three little pigs" was told.

Researcher: what is cool here Snow White? Snow white, Little Red Riding Hood, and Barbie: the velocipede. Researcher: oh, is it cool the velocipede of the shelter? What else is cool here? Snow White: I like the big bike. Researcher: and what place of the shelter do you like to stay? Snow White: this one. Researcher: Here? (making reference to the pedagogical sector of the institution where the research took place). Little Red Riding Hood nods affirmatively.

Both, the velocipede and the bicycle are toys used by the children in different areas of the institution. In those moments they interact with younger children, play by themselves or with others, and dispute or share toys.

Bronfenbrenner (1996) emphasizes that the developmental potential of a context increases when the physical environment offers some opportunities for locomotion, as well as objects for the children to use in spontaneous activities. In convergence, Rossetti-Ferreira et al. (2011) complement that institutions may contemplate the possibilities of the daily routine, adding value to areas and moments of play and interacting situations, so that they can be in contact with toys and not restricted to the presence of the educators.

However, Silva and Magalhães (2011) ponder that if on one hand the children make use of materials provided by the institutions, that often are not provided by their families, on the other hand they call attention to the quality of the relationships and care given to the sheltered children, once the "good things" mentioned by the children are, most of the time, "material conditions" in contrast to the care and attention given by the professionals. According to Groark, McCall and Fish (2011), the lack of responsive and available interactions between caregiver/child may contribute negatively to the development of children and adolescents institutionalized.

Another interesting episode concerns the first order they would give at the institution if they were kings, as the character from the story "Where the wild things are". Cinderella and snow White replied.

Researcher: What if you were kings like Max, what order would you give first here at the shelter? Cinderella: I would order them to buy food; I would order everybody to buy clothes. Snow White: I would order them to buy food, buy brushes, buy soap, and buy clothes.

In this extract, the replies of both girls seem to indicate what lacks or must be improved in the institution. Nonetheless, the institution holds food, clothes, as well as other objects such as soap and brushes. In this sense, the discussion may be directed to the matter of individuality, of the personal attendance that is much discussed 
by the authors (Rossetti-Ferreira et al., 2011; Corrêa, 2011).

At the institution where the research was held, objects as clothes, brushes, moisturizers, and soaps were shared by the children at the same dormitory. Therefore, Cinderella and Snow White might be pointing out the need of a more individualized attendance. During the data collection, the researcher spent an afternoon in the dormitory with the children that partook in this research; they were getting ready to go to the mass when Little Red Riding Hood asked the researcher to button her jeans. The girl then complained because it was too tight, another child that did not took part of the study, said: "That's what there is, right, aunt? Better than nothing" (note from the field diary).

Contrary to Cinderella, Snow White and Little Red Riding Hood, the other child demonstrates to be satisfied. The fact that she has been for a shorter period of time at the institution (less than a month) may be connected to this behavior. It is worth mentioning that, during conversation with the technicians at the institution, they report that as time passes by, the children who is housed for longer time at the institution (from two to three years) get more impatient and demonstrate more anxiety (Note from the field diary).

Rossetti-Ferreira et al. (2011) understand that dealing with the individualized and the customized, in a collective environment as a host institution, constitutes one of the greatest challenges to be faced by an institution. It is the professionals' obligation to find strategies that, at least, attenuate this lack of individuality.

According to Corrêa (2011), the host institution, as a collective context of care, is marked by the shared use of clothes, materials, and toys, putting the personal interest to the second plan. Nevertheless, her research shows that educators with longer professional qualification and longer personal and professional experiences with care tend to adopt more flexible practices, respecting the children's choices about what they would wear. Therefore, the educator would choose the clothes with the child, paying attention to and attending their preferences.

Snow White, at a conversation with the researcher, revealed that when she didn't what to eat the snack offered by the institution the nutritionist would give her a fruit instead (Note from the field diary). Strategies as that contribute for the children to have a more customized attendance, valuing the child as a single subject. According to Brazil (2009: p. 28), "planning the attendance at the service must enable, therefore, spaces to preserve the intimacy and privacy, including the use of objects that allow the children and the adolescents to make the difference between "mine, yours, and ours".

At the institution where the research was performed there was a wardrobe where the clothes used by the children were kept. At one occasion that the researcher helped the educators to choose the clothes the children from two dormitories would wear at the birthday party of one of the educator's daughter (note of the field diary), it was observed that even if the children didn't choose the clothes they would wear, the educators demonstrated to be careful on their choices. They would comment that one or other piece of clothing didn't match the child's personality.

Notice, in this sense, that the child is considered an active being on its developmental process, for aspects of the environment are modified according to each child's demands, having influence on the educator's choices of clothes each one would wear. To that matter, Bronfenbrenner (2011) states that the personal demands, as appearance and personality, gather the personal capacity of provoking or preventing reactions of the environment in favoring or inhibiting important interactions for the development, and consequently, for the psychological growth.

Based on the above mentioned, it is considered that for the human being to recognize itself as unique, it is essential that its individuality is preserved. Making choices, no matter how small, going through multiple experiences, discovering their preferences, in short, living with a certain level of autonomy, favors the development of perceptions the child has about itself. The sheltering services must not forgo spaces for the individuality of the child or adolescent. Otherwise, they will be interfering on the possibility of these children to grow as autonomous adults, capable of having an independent life (Prada et al., 2007).

\section{Final Consideration}

In ECA it is explicit that children must have their rights granted, which implies among other things, to consider the physical and social organization of host institutions through the perspective of their main actors: the children and the youngsters.

In the research scope, it is still common to treat the child as an object, that is, disregarded of its active role, with its personal characteristics that modify and, at the same time, are modified by the environment. Specially, 
the studies performed in host institutions must conceive the child as a social person, therefore, must investigate the sheltering services under the perspective of the sheltered child itself. Also, at the host space, by becoming their immediate environment (microsystem), it is imperative to listen to it and treat its perception as an important aspect to ponder about their behavior and development; as for studying the development, it is required to consider as a person interacting with real human beings, in real environments, even if they are real only for them (Bronfenbrenner, 2011).

In that direction, in the current study by investigating the children's perspectives about the institutional context, from a theoretical reference that approaches the physical and social aspects, and contributes for the state of art, once few researches ponder about the sheltering services from the child's point of view. In the academic scope, this investigation brings on its data (the children's speech) ways that lead to how the host institutions may organize themselves physically and socially to adequately attend the children, contributing for what is stated by ECA and the Technical Orientations. Therefore, it is important to create spaces/moments (such as Storytelling) so the children can express themselves whenever they feel the need, which signals the importance of creating public policies for more concrete actions to value the individuality in a way that considers the children as audience is priority, not mere users of hosting services.

It is believed, therefore, that from the ecological standpoint, the developmental potential of the host institution increases when it provides a physical and social context that motivates the children and adolescents in molar patters of activities and reciprocal interpersonal interactions, in a way to favor the establishment/strengthening of primary dyads between child-child, caregiver-child, family-child, etc.

Regarding the limitations of the research, it was noted the difficulty in performing the storytelling activity, as this activity confronted with other activities performed by the children at the institution, and the sample (only six children) made it difficult to compare groups. It is suggested that new studies are performed through the storytelling activities, with a variety of tales and for a longer period of time in order to acquire larger amount of information. Additionally, other ages should be approached and longer period of sheltering because, as mentioned in a note from field diary, children housed longer in the institution became more impatient and showed more anxiety. Thus, it would be interesting that other studies analyze this phenomenon with its potential reasons.

\section{References}

Almeida, I. G., Maehara, N. P., \& Rossetti-Ferreira, M. A. (2011). Reflections on Human Development and Institutional Context. In M. A. Rossetti-Ferreira, S. A. Serrano, \& I. G. Almeida (Eds.), The Institutionalcare in the Child's Perspective (pp. 119-172). São Paulo: Hucitec.

Alves, H. C., \& Emmel, M. L. G. (2008). Ecological Approach and Oral Narratives: A Study of Childvictims. Paidéia, 18, 85-100. http://dx.doi.org/10.1590/S0103-863X2008000100009

Amaral, D. C., Magalhães, C. M. C., \& Corrêa, L. S. (2015). Perceptions of Children in Institutional Sheltering: Interpersonal Relationships and Roles Played. Psychology, 6, 954-964. http://dx.doi.org/10.4236/psych.2015.68094

Bardin, L. (2011). Contentanalysis. São Paulo: Edições.

Batista, C. V. M. (2012). The Place of Play in the Educational Practices with Babies. In E. Bomtempo, \& L. C. Going (Eds.), Happy and Playful: A Reflection on the Playful Education (pp. 65-80). Rio de Janeiro, RJ: Wak.

Bernardi, D. C. F. (2010a). Shelters for Whom? In D. F. C. Bernardi (Eds.), Each Case Is Different-The Voice of Children and Adolescents in Residential Care (pp. 49-58). São Paulo: Shelters Collection Moving.

Bernardi, D. C. F. (2010b). Families in Vulnerable Situations. In D. F. C. Bernardi (Eds.), Each Case Is Different-The Voice of Children and Adolescents in Residential Care (pp. 37-43). São Paulo: Shelters Collection Moving.

Brazil, Child and Adolescent Statute-ECA (1990). Official Diary of the Union. Law No. 8.069, 16 July1990. Brasília: Federal Senate.

Brazil, NationalCouncil for the Rights of Children and Adolescents and the National Social Assistance Council (2009). According to the Technical Orientations for the Sheltering Services for Children and Adolescents. Brasília: Conanda.

Bronfenbrenner, U. (1996). The Ecology of Human Development: Natural Experiments and Planned. Porto Alegre: Artes Médicas.

Bronfenbrenner, U. (2011). The Bio-Ecology of Humandevelopment: Making the Mosthumanhumanbeings. Porto Alegre: Artes Médicas.

Cavalcante, L. I. C., Costa, L. N., \& Magalhães, C. M. C. (2012). Caretaking Behavior among Siblings in Children's Shelters. Psychology: Reflection and Criticism, 25, 165-173. http://dx.doi.org/10.1590/s0102-79722012000100020 
Christensen, P., \& Prout, A. (2002). Working with Ethical Symmetry in Social Research with Children. Childhood, 9, 477497. http://dx.doi.org/10.1177/0907568202009004007

Corrêa, L. S., \& Cavalcante, L. I. C. (2013). Shelter Educators: Conceptions on Development and Care Practices in Play Situation. Journal of Human Growth and Development, 23, 309-317. http://dx.doi.org/10.7322/jhgd.69506

Corrêa. L. S. (2011). Conceptions of Development and Carepractices for Children in Shelter Environment in the Developmental Niche Perspective. Unpublished Dissertation, Federal University of Pará, Belém.

Costa, L. N., Magalhães, C. M. C., \& Pedroso, J. S. (2014). Interactions between Siblings in Institutional Sheltering: A Case Study. Journal of Education and Human Development, 3, 155-166. http://dx.doi.org/10.15640/jehd.v3n4a14

Elage, B. (2010). Last Invaded This. In B. Elage (Ed.), Life Stories: Identity and Protection. The Story of Martin and Hisbrothers (pp. 73-85). São Paulo: Shelters Collection Moving.

Elbers, E. (2004). Conversational Asymmetry and the Child's Perspective in Developmental and Education Research. International Journal Disability, Development and Education, 51, 201-215. http://dspace.library.uu.nl/handle/1874/11219 http://dx.doi.org/10.1080/10349120410001687409

Garzella, M. C. \& Serrano, S. A. (2011). The Shelterunder the Lens of Children: Eyes and Voices of the Living in the Institution. In M. A. Rossetti-Ferreira, S. A. Serrano, \& I. G. Almeida (Eds.), The Institutionalcare in the Child's Perspective (pp. 199-234). São Paulo: Hucitec.

Groark, C. J., Mccall, R. B., \& Fish, L. (2011). Characteristics of Environments, Caregivers, and Children in Three Central American Orphanages. Infant Mental Health Journal, 32, 232-250. http://dx.doi.org/10.1002/imhj.20292

Martins, E., \& Szymanski, H. (2004). House of Playing: Meaning of Family for Institutionalized Children. Psychologystudies, 9, 177-187.

Minayo, M. C. S. (2010). The Challenge of Knowledge: Qualitative Health Research. São Paulo: Hucitec/Abrasco.

Platilha, R. da C., Magalhães, C. M. C., \& Pedroso, J. da S. (2014). Children's Oral Productions on Institutional Care. Perspectives of Development: A Multidimensional Approach, 2, 1-18.

http://periodicos.unb.br/index.php/perspectivasdodesenvolvimento/article/view/11620/9080

Pontes, F. A. R., \& Izar, P. (2005). The Study of Social Relations in the Ethological Perspective. In F. A. R. Pontes, C. M. C. Magalhães, R. C. S. Brito, \& W. L. B. Martin (Eds.), Topicsrelevant to the Construction of Contemporary Psychology (pp. 65-96). Belém: University Press-UFPA.

Prada, C. G., Williams, L. C. A., \& Weber, L. N. D. (2007). Shelters for Child Victims of Domestic Violence: Functioning Reported by Children and Managers. Psychology: Theory and Practice, 9, 14-25. http://www.nac.ufpr.br/artigos do site/2007 Abrigos para criancas vitimas de violencia domestica.pdf

Rossetti-Ferreira, M. A., Serrano, S. A., \& Costa do Amaral, N. R. (2011). Reflections on Human Development and Institutional Context. In M. A. Rossetti-Ferreira, S. A. Serrano, \& I. G. Almeida (Eds.), The Institutional Care in the Child's Perspective (pp. 60-85). São Paulo: Hucitec.

Silva, F. L., \& Magalhães, L. A. (2011). "Watch Robocop There Is Boring!” Talking to Children about Their Experiences in Institutional Shelter. In M. A. Rossetti-Ferreira, S. A. Serrano, \& I. G. Almeida (Eds.), The Institutional Care in the Child's Perspective (pp. 235-272). São Paulo: Hucitec.

Siqueira, A. C., \& Dell'Aglio, D. D. (2006). The Impact of Institutionalization on Children and Adolescents: A Literature Review. Psychology \& Society, 18, 71-80.

Souza, S. J., \& Castro, L. R. (2008). Searching with Children: Child Subjectivity, Dialogism and Gender Discourse. In S. H. V. Cruz (Eds.), The Child Speaks-Listening to Children in Research (pp. 52-78). São Paulo: Cortez.

Thorne, B. (2002). From Silence to Voice: Bringing Children More Fully into Knowledge. Childhood, 9, 251-254. http://dx.doi.org/10.1177/0907568202009003604

Trivellato, A. J., Carvalho, C., \& Vectore, C. (2013). Affective Listening: Possibilities of Use in Childcare Settings. Biannual Magazine of the Association of School and EducationalPsychology, 17, 299-307.

Vidigal, C. (2010). Shelter-Host Community and Socioeducation. In M. V. Baptista (Ed.), Shelter: Host Community and Socioeducation (pp. 84-85). São Paulo: Camargo Institute. 